\title{
Peningkatan Produktivitas dan Pendapatan Petani Melalui Penerapan Model Pengelolaan Tanaman Terpadu Padi Sawah di Kabupaten Pesawaran, Lampung
}

\author{
Increasing of Productivity and Farmers Income Through \\ Application of Integrated Crops Management Model on Paddy Low \\ Land at Pesawaran Regency, Lampung
}

\section{Robet Asnawi}

Balai Pengkajian Teknologi Pertanian Lampung

Jln. Hi. Z.A. Pagar Alam No. 1 A, Rajabasa-Bandar Lampung

Email : robetasnawi@yahoo.com

\begin{abstract}
One of maintain self-sufficiency is programs realized through the implementation of field school of integrated crops management (SLPTT) target increased quality rice with rice cultivation techniques, increased cropping intensity and productivity of rice. This research was conducted at SLPTT locations of Pesawaran regency (4 district), Lampung Province, from May until September 2010. The number of observed samples consisting of 180 units such as LL VUB (Field Laboratory of New Superior Variety) location is 60 units, LL non VUB location is 60 units and non SLPTT location is 60 units. The treatment applied SLPTT LL VUB is PTT (ICM) model such as superior verieties (Inpari 1, Inpari 7, Inpari 9 and Cigeulis), jajar legowo planting system (2:1 and 3:1), and site-specific fertilizer recommendation (Ministry Agriculture recommendation), and application pattern field school (PFS). At the SLPTT LL non $V U B$ location, treatment applied was Ciherang variety and fertilizer dose of local farmers (specific location), while non SLPTT location adapted to the habits of farmers. Data collected were production cost, yield components, and farming system problems. The results showed that the average productivity of paddy at the SLPTT LL VUB location is $7.174 \mathrm{~kg} / \mathrm{ha}$, SLPTT non VUB $6.737 \mathrm{~kg} / \mathrm{ha}$ and non SLPTT 4.587 $\mathrm{kg} / \mathrm{ha}$. Use of new superior varieties (VUB) increased productivity by 8,85\% compared with SLPTT non VUB and 47,13\% compared with non SLPTT. Farmer income in SLPTT LL VUB locations is Rp.17.410.000,-/ha $(R / C=3,15)$, SLPTT LL non VUB location Rp.13.488.806,-/ha $(R / C=2,46)$ and non SLPTT location Rp.9.885.625,/ha $(R / C=2,34)$. Through the application of VUB in SLPTT location can increase farmers' income $29,07 \%$ to $76,12 \%$.
\end{abstract}

Keywords: increasing, production, income, SLPTT, rice.

Diterima: 19-11-2013, disetujui: 17-01-2014

\section{PENDAHULUAN}

Setelah swasembada beras nasional tercapai kembali pada tahun 2008 salah satu tantangan yang dihadapi dalam rangka ketahanan pangan adalah bagaimana mempertahankan swasembada beras tersebut. Dalam kaitan ini Program Peningkatan Beras Nasional (P2BN) merupakan andalan 

pemerintah dan program tersebut dilaksanakan di seluruh propinsi (Balai Besar Penelitian Padi, 2009). Secara agronomis peningkatan produksi beras tersebut terutama diupayakan melalui peningkatan produktivitas disamping peningkatan luas tanam padi. Sedangkan secara kelembagaan program tersebut antara lain direalisasikan melalui pelaksanaan Sekolah Lapangan Tanaman Terpadu/SL PTT padi dengan sasaran meningkatnya kualitas teknik budidaya padi yang dilakukan petani, meningkatnya intensitas tanam dan produktivitas padi (Departemen Pertanian, 2009). Sekolah Lapangan Tanaman Terpadu (SLPTT) merupakan suatu tempat pendidikan non formal bagi petani untuk meningkatkan pengetahuan dan keterampilan dalam mengenali potensi, menyusun rencana usahatani, mengatasi permasalahan, mengambil keputusan dan menerapkan teknologi yang sesuai dengan kondisi sumberdaya setempat secara sinergis dan berwawasan lingkungan, sehingga usahataninya menjadi efisien, berproduktivitas tinggi dan berkelanjutan (Kementerian Pertanian, 2010).

Produksi beras nasional cenderung mengalami penurunan seiring dengan terjadinya deteriosasi dan penurunan kesuburan tanah akibat intensifikasi yang berkelanjutan. Salah satu upaya mengatasi kondisi tersebut dapat ditempuh melalui pendekatan pengelolaan tanaman (padi) terpadu (PTT) yang perupakan bentuk sinergisme antar komponen intensifikasi budidaya padi termasuk efisiensi pemupukan (Rachman dan Saryoko, 2008).

Para pemulia tanaman padi telah banyak menghasilkan beberapa varietas unggul, baik dalam bentuk varietas unggul baru, varietas unggul tipe baru maupun varietas padi hibrida. Keberhasilan pemulia tersebut baru dirasakan manfaatnya apabila tersedia benih bermutu dalam jumlah yang cukup untuk ditanam petani. Karena itu dukungan system perbenihan yang tangguh dan berkelanjutan sangat diperlukan untuk menjamin diseminasi varietas secara cepat.

Untuk tanaman padi, penggunaan varietas unggul telah memberikan kontribusi substansi terhadap peningkatan rata-rata produksi padi nasional yang saat ini telah mencapai 4,5 ton/ha. Penggunaan benih bermutu maupun berlabel di Indonesia relatif masih rendah yakni $30 \%$ untuk padi, $20 \%$ untuk jagung dan $15 \%$ untuk kedelai (Dirjen Tanaman Pangan, 2006).

Menurut Makarim et al. (2004), bahwa salah satu penyebab utama rendahnya produktivitas padi adalah karena varietas yang ditanam petani dewasa ini tidak mampu lagi berproduksi lebih tinggi akibat terbatasnya kemampuan genetik. Pelandaian produksi padi sawah sampai tahun terakhir masih berlanjut disebabkan sulitnya menaikan produktivitas padi di lahan sawah terutama di wilayah intensifikasi (Hasanudin, 2004 dan Fagi et al, 2002). Pelandaian produktivitas tersebut disebabkan oleh banyak faktor, antara lain penurunan kandungan bahan organik, penurunan penambatan $\mathrm{N}_{2}$ udara pada tanah sawah, penurunan kecepatan penyediaan hara $\mathrm{N}, \mathrm{P}$, dan $\mathrm{K}$ dalam tanah, penimbunan senyawa-senyawa toksik bagi tanaman ( gas $_{2} \mathrm{~S}$ ), asam-asam organik, ketidakseimbangan penyediaan hara, kahat hara mikro $(\mathrm{Cu}, \mathrm{Zn})$ kahat $\mathrm{Fe}$ dan $\mathrm{S}$, tanah terlalu reduktif, penyimpangan iklin, tekanan biotik dan varietas (Puslitbangtan, 2001).

Upaya terobosan untuk mengatasi peningkatan produktivitas padi terutama pada daerah pelandaian produktivitas adalah melalui pendekatan pengelolaan tanaman terpadu (PTT), suatu pendekatan untuk mengoptimalkan potensi secara terpadu, sinergi, dan partisipatif dalam upaya meningkatkan produksi padi di setiap daerah. Atau suatu pendekatan yang mempertimbangkan keserasian dan sinergisme antara komponen teknologi produksi (budidaya) dengan sumber lingkungan setempat. Hasil uji coba model PTT pada MK. 2001 di 8 propinsi (Sumatera Utara, Sumatera Barat, Jawa Barat, Jawa Tengah, Jawa Timur, Bali, Nusa Tenggara Barat dan Sulawesi Selatan) masingmasing pada lahan seluas 5 ha menunjukan adanya peningkatan produktivitas padi antara 7,1\% $38,4 \%$ dibanding teknologi petani (Fagi et al, 2002). Hasil uji coba tersebut menunjukan bahwa PTT mempunyai prospek yang baik untuk dikembangkan lebih lanjut. 
Model teknologi PTT merupakan sistem penerapan komponen teknologi yang sinergis satu dengan yang lainnya dengan mempertimbangkan karakteristik biofisik lingkungan tanaman, kondisi sosial, ekonomi dan budidaya petani yang diharapkan ada efek sinergisme terhadap pertumbuhan tanaman spesifik lokasi serta dinamis dalam susunan teknologinya karena adanya sistem introduksi inovasi secara terus menerus (Makarim dan Las, 2004). Melalui usaha ini diharapkan (1) kebutuhan beras nasional dapat dipenuhi, (2) pendapatan petani dapat ditingkatkan, dan (3) usaha pertanian padi dapat. Teknologi model PTT Padi menerapkan beberapa komponen teknologi spesifik lokasi yang sesuai dengan tingkat kebutuhan petani (Badan Penelitian dan Pengembangan Pertanian, 2007b). Pengelolaan Tanaman Terpadu (PTT) merupakan terobosan teknologi yang mensinergiskan berbagai teknologi untuk meningkatkan efisiensi input produksi. Menurut Makarim dan Las (2004) penerapan komponen PTT pada padi sawah di berbagai kabupaten di Indonesia ternyata menghasilkan gabah yang bervariasi dari 3 hingga $10 \mathrm{t} / \mathrm{ha}$.

Penelitian ini bertujuan untuk mengetahui peningkatan produktivitas dan pendapatan petani padi sawah melalui penerapan komponen PTT di Kabupaten Pesawaran.

\section{METODE}

Kegiatan ini telah dilakukan di Kabupaten Pesawaran mulai bulan Mei 2010 sampai September 2010. Lokasi kegiatan tersebar di 4 kecamatan penghasil padi di Kabupaten Pesawaran, yakni Gedung Tataan, Way Lima, Negeri Katon, dan Tegineneng. Total sampel yang diamati adalah 180 unit lokasi yang terdiri atas 60 unit lokasi SLPTT LL VUB, 60 unit lokasi SLPTT LL non VUB, dan 60 unit lokasi non SLPTT.

Pada lokasi SLPTT LL VUB diterapkan beberapa komponen PTT antara lain verietas unggul baru (Inpari 1, Inpari 9 dan Cigeulis), sistem tanam jajar legowo (2:1 dan 3:1), rekomendasi pemupukan spesifik lokasi Peratutan Menteri Pertanian Nomor 40/Permentan/ OT.140/4/2007, tentang Rekomendasi Pemupukan N, P, dan K Padi sawah spesifik Lokasi (Badan Penelitian dan Pengembangan Pertanian, 2007a), dan penerapan pola sekolah lapang (SL). Pada lokasi SLPTT non VUB perlakuan yang diterapkan adalah varietas Ciherang dan dosis petani setempat (SK Bupati Pesawaran), sedangkan pada lokasi non SLPTT disesuaikan dengan kebiasaan petani setempat.

Data yang dikumpulkan antara lain adalah data produksi, biaya produksi, dan pendapatan usahatani. Data dianalisis menggunakan analisis pendapatan, analisis kelayakan finansial, dan R/C ratio. Analisis pendapatan usahatani merupakan selisih antara penerimaan dengan semua biaya yang dikeluarkan (Soekartawi, 1995). Pendapatan usaha tani padi diperoleh dari perhitungan sebagai berikut :

$$
\mathrm{TL}=\mathrm{Y} \cdot \mathrm{Py}-\Sigma \mathrm{Xi} . \mathrm{Pi}
$$

Keterangan :

$\mathrm{TL}=$ pendapatan usaha tani padi $(\mathrm{Rp})$

$\mathrm{Y}=$ produksi padi $(\mathrm{kg} \mathrm{GKP})$

Py $=$ harga padi $(\mathrm{Rp} / \mathrm{kg}$ GKP)

$\mathrm{X} \mathrm{i}=$ penggunaan faktor ke-i

$\mathrm{Pi}=$ harga faktor ke-i.

Analisis kelayakan finansial digunakan untuk mengetahui tingkat efisiensi usahatani terhadap imbangan penerimaan atau biaya atau R/C ratio (Estiningtyas et al., 2012). Menurut Malian (2004), 
bahwa kelayakan usaha dilakukan untuk mengkaji kemungkinan keuntungan (profitability) atau kerugian yang diperoleh dari usaha tani yang dilakukan. Analisis yang digunakan dengan perhitungan Revnue Cost Ratio (R/C ratio), berdasarkan data jumlah penerimaan dan biaya yang dikeluarkan untuk usaha tani yang dilakukan. Jika $\mathrm{R} / \mathrm{C}$ ratio > 1, maka usaha tani yang dilakukan mengalami keuntungan atau layak untuk dikembangkan. Jika $\mathrm{R} / \mathrm{C}$ ratio $<1$, maka usaha tani tersebut mengalami kerugian atau tidak layak untuk dikembangkan. Selanjutnya jika $\mathrm{R} / \mathrm{C}$ ratio $=1$, maka kegiatan usaha tani berada pada titik impas (Break Event Point). R/C ratio dapat dianalisis dengan menggunakan rumus :

$$
\mathrm{R} / \mathrm{C} \text { ratio }=\frac{\text { Total penerimaan }(\mathrm{Rp})}{\text { Total biaya produksi }(\mathrm{Rp})}
$$

\section{HASIL DAN PEMBAHASAN}

\section{Input Produksi}

Penggunaan input produksi terutama pupuk an organik pada lokasi non SLPTT dan lokasi SLPTT terdapat perbedaan yang nyata. Pada lokasi non SLPTT dosis pupuk an organik menggunakan kebiasaan petani setempat, sedangkan pada lokasi SLPTT menggunakan dosis anjuran yang tertera dalam Peratutan Menteri Pertanian Nomor 40/Permentan/ OT.140/4/2007, tentang Rekomendasi Pemupukan N, P, dan K Padi sawah spesifik Lokasi (Badan Penelitian dan Pengembangan Pertanian, 2007a). Rata-rata penggunaan pupuk pada lokasi non SLPTT adalah $206,25 \mathrm{~kg}$ Urea/ha $+137,5 \mathrm{~kg}$ SP-18/ha + 106,25 kg Ponska/ha, sedangkan pada lokasi SLPTT digunakan 276,55 kg Urea/ha + $216,25 \mathrm{~kg} \mathrm{SP}-18 / \mathrm{ha}+465,63 \mathrm{~kg}$ Ponska/ha

Tabel 1. Dosis pupuk an organik pada lokasi SLPTT dan non SLPTT di Kabupaten Pesawaran tahun 2010.

\begin{tabular}{|c|c|c|c|c|c|c|c|c|c|c|c|}
\hline \multirow[b]{2}{*}{ No } & \multirow{2}{*}{$\begin{array}{c}\text { Jenis } \\
\text { Pupuk }\end{array}$} & \multicolumn{5}{|c|}{ Lokasi non SLPTT } & \multicolumn{5}{|c|}{ Lokasi SLPTT } \\
\hline & & $\begin{array}{c}\text { Gedung } \\
\text { Tataan }\end{array}$ & $\begin{array}{l}\text { Way } \\
\text { Lima }\end{array}$ & $\begin{array}{c}\text { Negeri } \\
\text { Katon }\end{array}$ & $\begin{array}{c}\text { Tegine- } \\
\text { neng }\end{array}$ & $\begin{array}{c}\text { Rata- } \\
\text { rata }\end{array}$ & $\begin{array}{c}\text { Gedung } \\
\text { Tataan }\end{array}$ & $\begin{array}{l}\text { Way } \\
\text { Lima }\end{array}$ & $\begin{array}{c}\text { Negeri } \\
\text { Katon }\end{array}$ & $\begin{array}{c}\text { Tegine- } \\
\text { neng }\end{array}$ & $\begin{array}{c}\text { Rata- } \\
\text { rata }\end{array}$ \\
\hline 1. & $\begin{array}{l}\text { Urea } \\
\text { (kg/ha) }\end{array}$ & 200 & 200 & 200 & 225 & 206,25 & 235 & 178,96 & 292,24 & 400 & 276,55 \\
\hline 2. & $\begin{array}{l}\text { SP-18 } \\
\text { (kg/ha) }\end{array}$ & 100 & 200 & 100 & 150 & 137,5 & 240 & 285 & 100 & 240 & 216,25 \\
\hline 3. & $\begin{array}{l}\text { Ponska } \\
(\mathrm{kg} / \mathrm{ha})\end{array}$ & 50 & 50 & 200 & 125 & 106,25 & 540 & 339,2 & 383,32 & 600 & 465,63 \\
\hline
\end{tabular}

\section{Peningkatan Produktivitas}

Hasil analisis pada Tabel 2 menunjukkan bahwa rata-rata produkitivitas padi sawah di lokasi SLPTT LL VUB adalah $6.737,04 \mathrm{~kg} / \mathrm{ha}$, lokasi SLPTT non VUB $6.174,81 \mathrm{~kg} / \mathrm{ha}$, dan lokasi non SLPTT 4.587,50 kg/ha. Lebih tingginya produktivitas padi sawah pada lokasi SLPTT LL VUB dibandingkan dengan lokasi lainnya disebabkan karena pada lokasi SLPTT LL VUB diterapkan model pengelolaan tanaman dan sumberdaya terpadu (PTT) seperti varietas unggul baru, jajar legowo dan pemupukan berimbang (dosis anjuran), sedangkan pada lokasi LL non VUB hanya diterapkan model PTT sebagian (pemupukan berimbang), dan pada lokasi non SLPTT tidak diterapkan model PTT. Hal ini sejalan dengan pernyataan Gani (2002), bahwa dalam PTT komponen-komponen utamanya bersinergi sesamanya sehingga secara kombinasi akan memberikan potensi yang besar untuk kenaikan hasil padi. Hasil pengkajian model PTT di Sukamandi memberikan hasil padi lebih dari $8 \mathrm{t} \mathrm{GKG/ha}$ dengan R/C rasio lebih besar dari 2,0 (Puslitbangtan, 2001). 
Tabel 2. Rata-rata produktivitas padi sawah pada lokasi SLPTT dan non SLPTT di Kabupaten Pesawaran, tahun 2010.

\begin{tabular}{ccccc}
\hline \multirow{2}{*}{ No. } & Kecamatan & \multicolumn{3}{c}{ Produktivitas (kg/ha) } \\
\cline { 3 - 5 } & & SLPTT LL VUB & SLPTT LL non VUB & non SLPTT \\
\hline 1. & Gedung Tataan & $6.548,76$ & $6.125,75$ & $4.500,00$ \\
2. & Way Lima & $6.722,85$ & $6.254,42$ & $4.300,00$ \\
3. & Negeri Katon & $5.892,36$ & $5.675,25$ & $4.800,00$ \\
4. & Tegineneng & $7.784,22$ & $6.643,82$ & $4.750,00$ \\
\hline \multicolumn{2}{r}{ Rata-rata } & $6.737,04$ & $6.174,81$ & $4.587,50$ \\
\hline
\end{tabular}

Jika dilihat pada Tabel 3, bahwa terjadi peningkatan produktivitas rata-rata 8,85\% lebih tinggi di lokasi LL VUB dibandingkan dengan LL non VUB, dan peningkatan produktivitas sebesar 47,13\% pada lokasi LL VUB dibandingkan dengan lokasi non SLPTT.

Tabel 3. Rata-rata peningkatan produktivitas padi sawah pada lokasi SLPTT dan non SLPTT di Kabupaten Pesawaran, tahun 2010.

\begin{tabular}{llcc}
\hline \multirow{2}{*}{ No } & \multirow{2}{*}{ Kecamatan } & \multicolumn{2}{c}{ Peningkatan produktivitas (\%) } \\
\cline { 3 - 4 } & & LL VUB Vs LL non VUB & LL VUB Vs non SLPTT \\
\hline 1 & Gedung Tataan & 6,91 & 45,53 \\
2 & Way Lima & 7,49 & 56,35 \\
3 & Negeri Katon & 3,83 & 22,76 \\
4 & Tegineneng & 17,16 & 63,88 \\
\hline \multicolumn{2}{r}{ Rata-rata } & 8,85 & 47,13 \\
\hline
\end{tabular}

Peningkatan produktivitas tersebut selain disebabkan oleh penggunaan varietas unggul baru (VUB) dan dosis pupuk anjuran, juga disebabkan oleh penerapan sistem tanam jajar legowo serta kondisi lingkungan yang sesuai bagi pertumbuhan dan produksi VUB yang diterapkan. Dengan sistem tanam jajar legowo semua barisan rumpun tanaman berada pada bagian pinggir tanaman yang biasanya memberikan hasil lebih tinggi (efek tanaman pinggir). Adanya barisan kosong (legowo) menyebabkan penyerapan nutrisi oleh akar menjadi lebih sempurna sehingga mempengaruhi pertumbuhan dan produksi tanaman padi yang dihasilkan (Setyanto dan Kartikawati, 2008).

Menurut Matsushima (1995), bahwa hasil padi ditentukan oleh komponen hasilnya sedangkan komponen hasilnya ditentukan oleh genetik tanaman maupun faktor lingkungan seperti iklim, hara, tanah, dan air. Ditambahkan oleh Makarim dan Las (2004), penerapan komponen PTT pada padi sawah di berbagai kabupaten di Indonesia ternyata menghasilkan gabah yang bervariasi dari 3 hingga $10 \mathrm{t} / \mathrm{ha}$.

Hasil analisis Tabel 4 menunjukkan bahwa hasil pengujian di 4 kecamatan di Kabupaten Pesawaran, penggunaan varietas unggul baru (VUB) Inpari 9 menghasilkan produktivitas $7.682,74 \mathrm{~kg} / \mathrm{ha}$ dan lebih tinggi dibandingkan dengan varietas Inpari $1(7.379,34 \mathrm{~kg} / \mathrm{ha})$, dan Cigeulis $(7.285,29 \mathrm{~kg} / \mathrm{ha})$. Hal tersebut sesuai dengan hasil penelitian Suprihatno et al (2009), bahwa potensi hasil varietas Inpari 9 adalah 9,3 ton/ha dan ratarata hasil 6,41 ton/ha. Selain itu varietas Inpari 9 memiliki bentuk tanaman tegak, agak tahan penyakit hawar daun bakteri ras III dan agak tahan penyakit tungro inokulum no. 013 .

Hasil penelitian pada masing-masing kecamatan (Tabel 4) menunjukkan bahwa penanaman VUB di Kecamatan Tegineneng menghasilkan rata-rata produktivitas padi tertinggi dibandingkan dengan kecamatan lainnya, yakni 9.157,90 kg/ha dan diikuti oleh Kecamatan Way Lima (7.469,83 kg/ha), Gedung Tataan (7.276,4 $\mathrm{kg} / \mathrm{ha})$, dan Negeri Katon $(5.892,36 \mathrm{~kg} / \mathrm{ha})$. Perbedaan produktivitas tersebut diduga karena tingginya daya adaptasi padi VUB pada kondisi lingkungan di Kecamatan Tegineneng dibandingkan dengan kecamatan lainnya. 
Robet Asnawi: Peningkatan Produktivitas dan Pendapatan Petani Melalui Penerapan Model Pengelolaan...

Tabel 4. Produktivitas beberapa varietas unggul baru (VUB) pada lokasi LL SLPTT di Kabupaten Pesawaran, tahun 2010.

\begin{tabular}{|c|c|c|c|c|c|c|}
\hline \multirow{2}{*}{ No } & \multirow{2}{*}{ Varietas } & \multicolumn{4}{|c|}{ Produktivitas (kg/ha) } & \multirow{2}{*}{ Rata-rata } \\
\hline & & Gedung Tataan & Way Lima & Negeri Katon & Tegineneng & \\
\hline 1 & Inpari 1 & $7.057,29$ & $7.081,72$ & $5.951,52$ & $9.426,84$ & $7.379,34$ \\
\hline 2 & Inpari 9 & $7.350,17$ & $7.749,76$ & $5.844,17$ & $9.786,84$ & $7.682,74$ \\
\hline \multirow[t]{2}{*}{3} & Cigeulis & $7.421,73$ & $7.578,01$ & $5.881,39$ & $8.260,02$ & $7.285,29$ \\
\hline & Rata-rata & $7.276,40$ & $7.469,83$ & $5.892,36$ & $9.157,90$ & $7.449,12$ \\
\hline
\end{tabular}

Pada lokasi non SLPTT digunakan varietas Ciherang dengan produktivitas $4.587 \mathrm{~kg} / \mathrm{ha}$. Hasil penelitian Suharno et al (2000) bahwa perbedaan hasil antara hasil penelitian dengan produksi di tingkat petani disebabkan oleh penggunaan benih yang bermutu rendah, teknologi yang belum sesuai anjuran dan adanya faktor pembatas lahan yaitu tingkat kesuburan yang rendah. Melalui perbaikan teknologi budidaya seperti pemupukan, waktu tanam yang tepat dan pengendalian jasad pengganggu, hasil padi sawah dengan menanam varietas unggul dapat mencapai 4,4 - 7,2 ton/ha. Menurut Makarim et al (2004), bahwa salah satu penyebab utama rendahnya produktivitas padi adalah karena varietas yang ditanam petani dewasa ini tidak mampu lagi berproduksi lebih tinggi akibat terbatasnya kemampuan genetik.

\section{Analisis Usaha tani}

Tabel 5. Analisis usaha tani tanaman padi sawah pada lokasi SLPTT LL VUB, SLPTT LL non VUB, dan SLPTT Kabupaten Pesawaran, tahun 2010.

\begin{tabular}{|c|c|c|c|c|}
\hline \multirow{2}{*}{ No } & \multirow{2}{*}{ Uraian } & \multicolumn{2}{|r|}{ Lokasi } & \multirow[b]{2}{*}{ Non SLPTT } \\
\hline & & SLPTT LL VUB & SLPTT LL non VUB & \\
\hline \multirow[t]{7}{*}{1.} & Saprodi & & & \\
\hline & - $\quad$ Benih $(\mathrm{Rp})$ & 150.000 & 150.000 & 150.000 \\
\hline & - $\quad$ Urea (Rp) & 470.135 & 470.135 & 350.625 \\
\hline & - $\quad \mathrm{SP} 18(\mathrm{Rp})$ & 475.750 & 475.750 & 302.500 \\
\hline & - $\quad$ Ponska (Rp) & 1.257 .201 & 1.257 .201 & 286.875 \\
\hline & - $\quad$ Pestisida (Rp) & 330.000 & 330.000 & 316.250 \\
\hline & Total Biaya Saprodi & 2.683 .086 & 2.683 .086 & 1.406 .250 \\
\hline \multirow[t]{10}{*}{2.} & Tenaga Kerja & & & \\
\hline & - $\quad$ Pengolahan tanah (Rp) & 749.125 & 749.125 & 749.125 \\
\hline & - $\quad$ Penyemaian (Rp) & 49.750 & 49.750 & 49.750 \\
\hline & - $\quad$ Penanaman $(\mathrm{Rp})$ & 568.750 & 568.750 & 568.750 \\
\hline & - $\quad$ Pemupukan 2 kali (Rp) & 57.000 & 57.000 & 57.000 \\
\hline & - $\quad$ Penyiangan $(\mathrm{Rp})$ & 439.500 & 439.500 & 439.500 \\
\hline & - $\quad$ Pengendalian HPT (Rp) & 116.500 & 116.500 & 116.500 \\
\hline & - $\quad$ Panen $(\mathrm{Rp})$ & 836.250 & 836.250 & 836.250 \\
\hline & Total Biaya TK $(\mathrm{Rp})$ & 2.816 .875 & 2.816 .875 & 2.816 .875 \\
\hline & Total Biaya Produksi (Rp) & 5.499 .961 & 5.499 .961 & 4.223 .125 \\
\hline 3. & Penerimaan & & & \\
\hline 4. & Produksi (kg/ha) & 7.449 & 6.175 & 4.588 \\
\hline 5. & Harga $(\mathrm{Rp} / \mathrm{kg})$ & 3.075 & 3.075 & 3.075 \\
\hline 6. & Nilai Hasil (Rp) & 22.910 .367 & 18.988 .767 & 14.108 .750 \\
\hline 7. & Pendapatan (Rp/ha) & 17.410 .406 & 13.488 .806 & $9.885,625$ \\
\hline 8. & $\mathrm{R} / \mathrm{C}$ ratio & 3,15 & 2,46 & 2,34 \\
\hline
\end{tabular}

Hasil analisis usahatani padi sawah pada lokasi LL VUB menunjukkan bahwa rata-rata pendapatan petani adalah Rp. 17.410.406,-/ha dengan R/C ratio 3,15, sedangkan pada lokasi SLPTT 
LL non VUB rata-rata pendapatan petani adalah Rp. 13.488.806,-/ha dengan R/C ratio 2,46 dan pada lokasi non SLPTT rata-rata pendapatan petani padi sawah adalah Rp. 9.885.625,-/ha dengan R/C ratio 2,34 (Tabel 5). Secara statistik terjadi peningkatan pendapatan petani sebesar 29,07\% melalui penerapan komponen PTT pada lokasi SLPTT LL VUB dibandingkan dengan SLPTT LL non VUB dan meningkatkan pendapatan sebesar 76,12\% jika dibandingkan dengan non SLPTT (Tabel 6). Secara keseluruhan usahatani padi sawah di Kabupaten Pesawaran memiliki nilai R/C > 1, yang berarti layak untuk diusahakan.

Tingginya pendapatan petani pada usahatani padi sawah pada lokasi SLPTT LL VUB dibandingkan dengan SLPTT LL non VUB dan non SLPTT disebabkan karena penerapan manajemen PTT pada usahatani SLPTT LL VUB, sedangkan SLPTT LL non VUB dan non SLPTT belum sepenuhnya dilakukan. Komponen PTT yang diterapkan pada lokasi SLPTT LL VUB antara lain penggunaan benih unggul berlabel varietas Inpari 1, Inpari 9, dan Cigeulis, pemupukan berimbang dan sesuai rekomendasi, serta penerapan sistem tanam jajar legowo (2:1 dan 3:1). Hal tersebut menyebabkan tingginya produksi dan pendapatan petani yang dihasilkan pada lokasi SLPTT LL VUB dibandingkan dengan lokasi SLPTT LL non VUB dan non SLPTT. Hasil penelitian Peng (1994) bahwa potensi hasil padi tipe baru dapat mencapai 30-50\% lebih tinggi daripada varietas yang ada, pada lingkungan yang sesuai di daerah tropis. Ditambahkan oleh Suwalan et al. (2004) bahwa respon tanaman terhadap pemberian pupuk akan meningkat apabila pupuk yang digunakan tepat jenis, dosis, waktu dan cara pemberian.

Tabel 6. Hasil analisis ekonomi peningkatan pendapatan usahatani padi pada lokasi SLPTT LL VUB, SLPTT LL non VUB, dan non SLPTT di Kabupaten Pesawaran, tahun 2010.

\begin{tabular}{clrc}
\hline No & \multicolumn{1}{c}{ Uraian } & Pendapatan (Rp/ha) & Peningkatan (\%) \\
\hline 1. & LL VUB & 17.410 .406 & - \\
2. & LL non VUB & 13.488 .806 & 29,07 (LL VUB vs LL non VUB) \\
3. & Non SLPTT & 9.885 .625 & 76,12 (LL VUB vs non SLPTT) \\
\hline
\end{tabular}

\section{KESIMPULAN}

Produktivitas rata-rata padi sawah pada lokasi SLPTT LL VUB adalah $6.737 \mathrm{~kg} / \mathrm{ha}$ lebih tinggi dari lokasi SLPTT LL non VUB $7.174 \mathrm{~kg} / \mathrm{ha}$ dan non SLPTT $4.587 \mathrm{~kg} / \mathrm{ha}$. Penggunaan varietas unggul pada lokasi SLPTT LL VUB meningkatkan produktivitas sebesar 8,85\% dibandingkan dengan SLPTT LL non VUB dan 47,13\% dibandingkan dengan lokasi non SLPTT. Rata-rata pendapatan usahatani padi pada lokasi SLPTT LL VUB adalah Rp.17.410.000,-/ha $(\mathrm{R} / \mathrm{C}=3,15)$, lokasi SLPTT LL non VUB Rp. 13.488.806,-/ha $(\mathrm{R} / \mathrm{C}=2,46)$ dan lokasi non SLPTT Rp.9.885.625,-/ha $(\mathrm{R} / \mathrm{C}=2,34)$. Melalui penerapan VUB pada lokasi SLPTT LL VUB mampu meningkatkan pendapatan petani sebesar $29,07 \%$ sampai $76,12 \%$.

\section{DAFTAR PUSTAKA}

Badan Penelitian dan Pengembangan Pertanian. 2007a. Rekomendasi Pemupukan N, P, dan K Padi sawah spesifik Lokasi. Badan Penelitian dan Pengembangan Pertanian, Departemen Pertanian. 97 halaman. 
Robet Asnawi: Peningkatan Produktivitas dan Pendapatan Petani Melalui Penerapan Model Pengelolaan...

Badan Penelitian dan Pengembangan Pertanian. 2007b. Pengelolaan Tanaman Terpadu (PTT). Badan Litbang pertanian. Departeman Pertanian. Jakarta.

Balai Besar Penelitian Padi. 2009. Peningkatan Produksi Padi Melalui IP Padi 400. PedumIP Padi 400. Balai Besar Penelitian Padi, Badan Penelitian dan Pengembangan Pertanian. 48 halaman.

Departemen Pertanian. 2009. Pedoman Umum PTT Padi Sawah. Badan Penelitian dan Pengembangan Pertanian, Departemen Pertanian. 20 halaman.

Dirjen Tanaman Pangan. 2006. Konsepsi Subsidi Benih. Direktorat Jenderal Tanaman Pangan, Jakarta

Estiningtyas, W., R.Boer., I. Las, dan A. Buono. 2012. Analisis Usahatani Padi Untuk Mendukung Pengembangan Asuransi Indeks Iklim (Weather Index Insurance): Studu Kasus di Kabupaten Indramayu. Jurnal Pengkajian dan Pengembangan Teknologi Pertanian 15 (2): 158-170.

Fagi. A.M, I.Las, M. Syam, A.K. Makarim, dan A. Hasanuddin. 2002. Penelitian Padi Menuju Repolusi Hijau Lestari. Badan Litbang Pertanian, Jakarta.

Gani, A. 2002. Pengelolaan Tanaman dan Sumberdaya Terpadu danSinergisme Komponen Teknologi. Makalah pada pelatihan tenaga Pendamping. Kegiatan P3T, Bogor-Sukamnadi, 7 - 12 Maret 2002.

Hasanuddin, A. 2004. Pengelolaan Tanaman Padi Terpadu : Suatu Strategi Teknologi Spesifik Lokasi. Makalah Panduan Pelatihan Pemasyarakatan dan Pengembangan Padi Varietas Unggul Tipe Baru, Balitpa-Sukamandi, 31 Maret - 3 April 2003.

Kementerian Pertanian. 2010. Pedoman Pelaksanaan Sekolah Lapangan Tanaman Terpadu (SL-PTT) Padi, Jagung, Kedelai, dan Kacang Tanah Tahun 2010. Direktorat Jenderal Tanaman Pangan, Kementerian Pertanian. 123 halaman.

Makarim, A.K. dan I. Las, 2004. Terobosan Peningkatan Produktivitas Padi Sawah Irigasi Melalui Pengembangan Model Pengelolaan Tanaman dan Sumberdaya Terpadu (PTT). Seminar Kebijakan Padi pada Pekan Padi Nasional II, 15 Juli 2004, Sukamandi.

Makarim, A.K., I. Las., A.M. Fagi, I.N. Widiarta, dan D. Pasaribu. 2004. Padi Tipe Baru. Budidaya dengan pendekatan pengelolaan tanaman terpadu. Balai Penelitian Padi. Sukamandi. 48p.

Malian, A.H. 2004. Analisis Ekonomi Usahatani dan Kelayakan Finansial Teknologi Pada Skala Pengkajian. Bahan Pelatihan "Analisis Finansial dan Ekonomi Bagi Pengembangan Sistem dan Usaha Agribisnis Wilayah". Pusat Penelitian Sosial Ekonomi Pertanian dan Proyek Pengkajian Teknologi Pertanian Partisipatif. 28 halaman.

Matsushima, S. 1995. Physiology of high yielding rice plants from the viewpoint of yield components (chapter 8). In.Matsuo et al. (Eds). Science of the rice plant. Volume-2: Physiology. p.737753.

Peng, S.G.S. 1994. Evaluation of the new plant ideotype for increased yield potential. In: K.G. Cassman $(E d)$. Breaking the Yield Barrier. International Rice Research Institute, Philippines. P.5-20.

Puslitbangtan, 2001. Pengelolaan Tanaman Terpadu : Pendekatan Inovatif Sistem Produksi Padi. Warta Penelitian dan Pengembangan Pertanian Vol. 23 No. 2. Badan Litbang PertanianPuslitbangtan Bogor. 
Rachman, B dan A. Saryoko. 2008. Analisis titik impas dan laba usahatani melalui pendekatan pengelolaan tanaman terpadu di Kabupaten Lebak-Banten. Jurnal Pengkajian dan Pengembangan Teknologi Pertanian 11 (1): 54-60.

Setyanto, P dan R. Kartikawati. 2008. Sistem Pengelolaan Tanaman Padi Rendah Emisi Gas Metan. Jurnal Penelitian Tanaman Pangan, Vol 27 (3): 154-163.

Soekartawi. A. 1995. Analisis Usahatani. Universitas Indonesia. Jakarta Suharno, Idris, M. Darwin, Sahardi dan Subandi, 2000. Keunggulan dan peluang pengembangan padi varietas Konawe. Laporan Hasil Pengkajian/Penelitian BPTP Sulawesi Tenggara. 19p.

Suprihatno, B., A.A. Daradjat, Satoto, Baehaki, S.E., Suprihanto, A. Setyono, S.D. Indrasari, M.Y. Samaullah, dan H. Sembiring. 2009. Deskripsi Varietas Padi. Balai Besar Penelitian Padi, Badan Penelitian dan Pengembangan Pertanian. 105 halaman.

Suwalan, S., Nana, S., Bambang S., R. Kusmawa dan Didi Ardi, 2004. Penggunaan Pupuk Alternatif pada Tanaman Padi Sawah di Kabupaten Garut, Jawa Barat. Kebijakan Perberasan dan Inovasi Teknologi Padi. Puslitbang Tanaman Pangan, Bogor. 